\title{
THE CHARACTERIZATION OF A MEMBRANE-BOUND PROTEIN CARBOXYLMETHYLATION SYSTEM IN BRAIN
}

\author{
Otto Z. Sellinger, Craig M. Kramer, Carolyn Fischer-Bovenkerk \\ and Cassandra M. Adams \\ Mental Health Research Institute, University of Michigan Medical Center, Ann Arbor, MI 48109, U.S.A.
}

(Received 17 June 1986; accepted 8 August 1986)

\begin{abstract}
The membrane-bound component of the cerebral protein carboxylmethylation system, consisting of the membrane-bound enzyme protein carboxylmethyltransferase II (PCMT) and of selected membrane-bound methyl accepting proteins (MAP), is described. The cellular localization of this membrane-bound protein carboxylmethylation system is shown to include, in addition to nerve cell bodies and purified synaptosomes, astrocytes and oligodendroglia. The membrane-bound nature of the protein carboxylmethylation system was investigated and these studies revealed a tight association which exposure to several detergents could only partially solubilize. The membrane-bound PCMT could be shown to undergo activation after treatment with $\mathrm{Na}$-deoxycholate and CHAPs, while after its detergent-induced solubilization PCMT activation was observed after Na-deoxycholate, Nonidet P-40 and Lubrol-P. Solubilization of the carboxylmethylation system in CHAPS appeared to be more effective at $0^{\circ} \mathrm{C}$ than at $25^{\circ} \mathrm{C}$ or $37^{\circ} \mathrm{C}$. Detergent treatment was shown to be deleterious to the MAPs as PCMT substrates, particularly when the exposure was extended to more than $1 \mathrm{~h}$. These observations prompted exposure of the brain membranes and of their Lubrol- $\mathrm{P}_{\mathrm{x}}$ and Nonidet $\mathrm{P}-40$ extracts to $\mathrm{NH}_{4} \mathrm{OH}$, treatment which promotes the conversion of protein asparagine residues to atypical L-isoaspartate residues, recently shown (in synthetic peptides) to be the single most effective residue recognized for carboxylmethylation by PCMT. We found up to a $400 \%$ enhancement of the carboxylmethylation of solubilized membrane MAPs by the equally solubilized PCMT (which resisted the alkaline treatment virtually unscathed) after $90 \mathrm{~min}$ at $37^{\circ} \mathrm{C}$ in $0.05 \mathrm{M} \mathrm{NH}_{4} \mathrm{OH}$. However, when brain membrane Lubrol- $\mathrm{P}_{\mathrm{x}}$ extracts were first subjected to bis(I,I-trifluoroacetoxy)-iodobenzene, a reagent which converts the carboxyamide group of protein-bound asparagine to the corresponding primary amine, the amount of MAPs susceptible to be acted upon by $0.05 \mathrm{M} \mathrm{NH}_{4} \mathrm{OH}$ became greatly reduced. Finally, acidic slab gel electrophoresis of membrane-bound MAPs, carboxyl- $\left[{ }^{3} \mathrm{H}\right]-$ methylated by the membrane-bound PCMT, revealed the presence of about 12 radioactive protein bands, ranging in $\mathrm{MW}$ from under $20 \mathrm{KDa}$ to about $90 \mathrm{KDa}$.
\end{abstract}

The carboxylmethylation of proteins is catalyzed by the enzyme protein carboxylmethyltransferase (PCMT, EC 2.1.24) (Kim, 1984; Clarke, 1985; Billingsley and Lovenberg, 1985). Although intracellular localization studies in cow and rat brain have revealed high levels of PCMT activity in the cytosol, a membrane-bound (mb) component of cerebral PCMT has also been briefly examined (Diliberto and Axelrod, 1976; Iqbal and Steenson, 1976; Clark et al., 1979; Brown, 1984; Sellinger et al., 1985; Johnson and Aswad, 1985a; Fischer-Bovenkerk et al., 1986). Similarly, it has been reported that the endogenous substrates of brain PCMT, i.e. the methyl accepting proteins, or MAPs, may be both cytosolic and membrane-bound (Gagnon et al., 1981; Aswad and Deight, 1983a, Billingsley et al., 1985a, b; Johnson and Aswad, 1985a; Clarke, 1985). Most recently, a survey of MAPs serving as substrates for an isozyme of the cytosolic bovine brain PCMT (Aswad and
Deight, 1983b) disclosed many to be membranebound (Johnson and Aswad, 1985a). This study also briefly noted that, in rat brain, some mb-MAPs may be carboxylmethylated by a mb-form of the PCMT. We have briefly reported similar observations (Sellinger et al., 1985; Fischer-Bovenkerk et al., 1986). A cell-specific role for brain PCMT has recently been inferred from its immunohistochemically determined localization, which revealed a predominantly neuronal distribution (Billingsley et al., 1985a). Regionally, intense PCMT activity was observed in the substantia nigra, the locus coeruleus and the paraventricular nucleus (Billingsley and Balaban, 1985), with implications of a special role for the enzyme in presynaptic monoaminergic neurons and in the release and/or processing of neurohypophyseal peptides. It has been reported previously that calmodulin (Gagnon et al., 1981), cAMP phosphodiesterase, $\mathrm{Ca}^{2+}$-calmodulin-dependent protein kinase 
and the calmodulin-activated phosphatase, calcineurin (Billingsley and Lovenberg, 1985; Billingsley et al., 1985b, c; Gupta et al., 1985), constitute segments of a functionally important cerebral carboxylmethylation cascade designed to modulate $\mathrm{Ca}^{2+}$-calmodulin-dependent reactions. However, since in these predominantly in vitro studies (Clarke, 1985), highly purified, cytosolic PCMT of both neural and non-neural origin was utilized to carboxylmethylate $\mathrm{mb}$ - and cytosolic neural proteins, some of them in a highly purified state, it is not possible to affirm that the reported findings reflect in situ occurring events.

The present report documents the presence, and characterizes the properties, of a membrane-bound protein carboxylmethylation system in brain which consists of a tightly embedded membrane-bound PCMT able to act on its equally tightly membranebound MAPs.

\section{EXPERIMENTAL PROCEDURES}

\section{Materials}

S-adenosyl-L-methionine (di-p-toluenesulfonate salt) and S-adenosyl-L-homocysteine were gifts of Dr G. Stramentinoli, BioResearch, Liscate, Italy. Synapsin (about 60\% pure) from cow brain was a gift of Dr T. Ueda, of this Institute. Crystalline ovalbumin, bovine serum albumin (BSA), calmodulin, Nonidet P-40, Lubrol- $\mathrm{P}_{\mathrm{x}}$, Triton X-100, Ficoll (type 4000-DL), Na-deoxycholate, 3-[(3-cholamidopropyl)-dimethylammonio]1-propanesulfonate (CHAPS), Percoll and the density marker beads, TPCK-trypsin, acetylated trypsin, soybean trypsin inhibitor and Coomassie Blue were from Sigma Co., St. Louis Mo. The MW standards for electrophoresis were from Pharmacia. Acrylamide and N,$\mathrm{N}^{\prime}$-bis-methylene acrylamide were from Serva, Garden City Park, New York. Bis-(I,I-trifluoroacetoxy)-iodobenzene (BTI) was from Fluka Chem. Corp., Hauppague, N.Y. En ${ }^{3}$ Hance was from New England Nuclear, Boston, Mass. $\left[{ }^{3} \mathrm{H}\right]-$ methyl-S-adenosyl-L-methionine $(1 \mathrm{mCi} / \mathrm{ml}$, Cat. no. 24051 ), with a nominal specific radioactivity of $10-15 \mathrm{Ci} /$ mmol was from ICN, Irvine, Calif. All other reagents were the best analytical grade available. Samples of purified, cytosolic rat brain PCMT were generously donated by Dr M. L. Billingsley, Dept of Pharmacology, Pennsylvania State University, Hershey, $\mathrm{Pa}$.

\section{Animals}

Cow cerebella were from a local slaughterhouse. The organ was excised, immediately refrigerated and homogenized within $3 \mathrm{~h}$. Rats were male Sprague-Dawley, 2-4 months old.

\section{Methods}

\section{Preparation of tissue fractions}

Rat cerebra and cerebella and cow cerebella were homogenized in about 10 volumes of buffer $(50 \mathrm{mM}$ Na-phosphate, $\mathrm{pH} 6.5$ or $20 \mathrm{mM}$ Tris-citrate, $\mathrm{pH} \mathrm{7.4)} \mathrm{and} \mathrm{the} \mathrm{homogenate}$ centrifuged at $1000 \mathrm{~g}$, The resulting supernatant was centrifuged at $10,000 \mathrm{~g}$ or, in later experiments, at $17,500 \mathrm{~g}$ for $30 \mathrm{~min}$. The resulting pellet, washed once (pellet No. 2) or 6 times (pellet No. 6) was used in most experiments. In a few instances, specified in the appropriate Figure and Table legends the $1000 \mathrm{~g}$ step was omitted and a high-speed $(100,000 \mathrm{~g}, 60 \mathrm{~min})$ pellet and supernatant were also obtained. In one instance (Fig. 1B) the homogenizing buffer was $10 \mathrm{mM} \mathrm{Na}$-phosphate, $\mathrm{pH} 6.8$, containing $1 \mathrm{mM}$ EDTA, $0.1 \mathrm{mM}$ benzethonium chloride, $0.1 \mathrm{mM}$ phenylmethylsulfonylchloride, $0.2 \% \mathrm{Na}$-azide, $0.02 \%$ bacitracin and $2 \mathrm{mM}$ benzamidine- $\mathrm{HCl}$ (protease inhibitor cocktail).

Preparation of cells, cell components and subcellular organelles

Synaptosomes. The procedure utilizing Percoll gradients (Nagy and Delgado-Escueta, 1984) was followed. Percoll layer C (10-16\% interface) contained purified synaptosomes. To obtain synaptosomal membranes, synaptosomes were collected at $20,000 \mathrm{~g}$ for $20 \mathrm{~min}$ in rotor SW-27 (Beckman) and the pellet was resuspended in $1 \mathrm{ml}$ of $0.32 \mathrm{M}$ sucrose ( $\mathrm{pH} 7.5$ ) to which $10 \mathrm{ml}$ of $1 \mathrm{mM} \mathrm{Na-phosphate}$ (pH 7.5) buffer, containing $0.1 \mathrm{mM}$ EDTA were added. After $30 \mathrm{~min}$ at $0 . \mathrm{C}$, the lysed suspension was centrifuged at $10,000 \mathrm{~g}$ for $30 \mathrm{~min}$. The pellet (synaptosomal membranes) was resuspended in $1 \mathrm{ml}$ of $50 \mathrm{mM} \mathrm{Na}$-phosphate buffer, pH 6.5 .

Neuronal perikarya. The procedure of Sellinger et al. (1971) was used.

Astrocytes. The procedure of Farooq and Norton (1978) was used without significant modifications. Acetylated and TPCK-trypsin were used interchangeably with equal results.

Oligodendroglia. The procedure of Berti-Mattera et al. (1984) was used. It was confirmed that, for best results, it was necessary to omit $\mathrm{Ca}^{2+}$ and $\mathrm{Mg}^{2+}$ from all solutions. In a few experiments, soybean trypsin inhibitor was used to arrest trypsinization, with no apparent benefit.

\section{Phase contrast microscopy.}

The isolated cells were monitored for purity and integrity by phase contrast microscopy. The appearance of the isolated cells matched in all respects that of the cells shown in the publications describing their isolation.

\section{Analytical}

Protein was determined by the method of Peterson (1977).

\section{Acidic slab gel electrophoresis}

The procedure described by Aswad and Deight (1983a) was used. A vertical slab system (SE 400) (Hoefer Scientific Products, San Francisco, Calif.), powered by $180 \mathrm{~V}$ for $3.5 \mathrm{~h}$ at RT provided the desired separations. After electrophoresis of the radioactive proteins, the gel slabs were stained with $0.25 \%$ Coomassie Blue for $30 \mathrm{~min}$, treated with En ${ }^{3}$ Hance and immediately dried before being placed in contact with XAR-5 X-ray film for exposure to $-70^{\circ} \mathrm{C}$.

\section{The assay of PCMT activity}

(a) Acting on endogenous MAPs. The procedure of Diliberto and Axelrod $(1974,1976)$ was used. Each tube (F.V.: $255 \mu 1$ ) contained $5 \mu$ curies of $\left[{ }^{3} \mathrm{H}\right]$-methyl SAM and the following, at the final concentration: SAM $(20 \mu \mathrm{M})$, EDTA $(0.4 \mathrm{mM})$, dithiothreitol $(1.2 \mathrm{mM})$ and up to $200 \mu 1$ of tissue. Unless otherwise stated, the incubation was for $30 \mathrm{~min}$ at $37^{\circ} \mathrm{C}$. Carboxylmethylation was arrested by the addition of $1 \mathrm{ml}$ of $20 \%(\mathrm{w} / \mathrm{v})$ TCA followed by $1 \mathrm{mg}$ of BSA as carrier. After $15 \mathrm{~min}$ on ice, the tubes were centrifuged at $3400 \mathrm{rpm}$ for $15 \mathrm{~min}$. The pellets were sus- 
pended in $0.5 \mathrm{ml}$ of $0.125 \mathrm{M}$ "borax" $\left(\mathrm{Na}_{2} \mathrm{~B}_{4} \mathrm{O}_{7}-10 \mathrm{H}_{2} \mathrm{O}\right)$, pH 10.7 and were incubated for $5 \mathrm{~min}$ at $37^{\circ} \mathrm{C}$. Then, $1.2 \mathrm{ml}$ of a $3: 2(\mathrm{v} / \mathrm{v})$ mixture of toluene: isoamyl alcohol were added, the tubes were thoroughly vortexed and centrifuged at $4000 \mathrm{rpm}$ for $5 \mathrm{~min}$. Two $0.5 \mathrm{ml}$ aliquots of the upper phase, containing the released $\left[{ }^{3} \mathrm{H}\right]-\mathrm{CH}_{3} \mathrm{OH}$ (Diliberto and Axelrod, 1974), were placed into 2 glass scintillation vials, one for immediate processing (total dpm) and the other for the determination of the non-volatile radioactivity (Diliberto and Axelrod, 1974, 1976; Brown, 1984). The non-volatile radioactivity did not exceed $20 \%$ of the total $\mathrm{dpm}$ when mb-PCMT acting on endogenous MAPs was being determined and was below $5 \%$ of the total radioactivity when PCMT acting on added MAPs was being assayed. PCMT activity is expressed as picomoles of $\left[{ }^{3} \mathrm{H}\right]$ methyl transferred from $\left[{ }^{3} \mathrm{H}\right]$ methyl SAM to methyl accepting proteins (MAPs) (endogenous or added).

(b) Acting on added MAPs. The above assay was used, unmodified, except that ovalbumin $(10 \mu \mathrm{g} /$ tube $)$ or another purified protein (see text and Table 6 for amounts) was added to the incubation.

(c) After preincubations and pretreatments. Various preparations containing the PCMT-MAP system in mbor detergent-solubilized-form were exposed to $0.05 \mathrm{M}$ $\mathrm{NH}_{4} \mathrm{OH}, 50 \%(\mathrm{v} / \mathrm{v})$ dimethylformamide, containing $0.01 \mathrm{M}$ trifluoroacetic acid \pm bis-(I,I-trifluoroacetoxy)-iodobenzene (BTI), and to several other treatments (see text), including prolonged exposure to $60^{\circ} \mathrm{C}$. The PCMT activity remaining after these treatments was determined and where found inactivated, the enzyme protein was replaced, for subsequent MAP determinations, by the purified, cytosolic rat brain PCMT. For further details, see legends to appropriate Tables.

\section{RESULTS}

\section{The association of PCMT with membranes}

(a) PCMT acting on added MAPs. Several experiments were performed to establish the membrane association of brain PCMT. Rat cerebrum homogenates were prepared in $50 \mathrm{mM} \mathrm{Na}$ phosphate buffer, pH 6.5 and cow cerebellum (Iqbal and Steenson, 1976) homogenates in $20 \mathrm{mM}$ Tris-citrate buffer, $\mathrm{pH}$ 7.4. PCMT activity was determined in the following fractions: the homogenate, the $10,000 \mathrm{~g}$ pellets and supernatants $\left(P_{1}\right.$ and $\left.S_{1}\right)$; the $100,000 g$ pellets and supernatants derived from $S_{1}\left(P_{3}\right.$ and $\left.S_{3}\right)$ and the $100,000 \mathrm{~g}$ pellets and supernatants derived from a suspension of $P_{1}$ in $20 \mathrm{ml}$ of $0.1 \%$ Triton X-100 $\left(P_{\mathrm{T}}\right.$ and $S_{\mathrm{T}}$ ). After normalizing for recoveries (range 78-
$108 \%)$, relative to the initial homogenates $(100 \%)$, the percentages of PCMT in membrane-bound form ranged from 22 to $27 \%$ in $\mathrm{P}_{1}\left(\mathrm{P}_{1}+\mathrm{S}_{1}=100 \%\right)$, $44-56 \%$ in $\mathrm{P}_{\mathrm{T}}\left(\mathrm{P}_{\mathrm{T}}+\mathrm{S}_{\mathrm{T}}=100 \%\right)$ and $14-19 \%$ in $\mathrm{P}_{3}$ $\left(\mathrm{P}_{3}+\mathrm{S}_{3}=100 \%\right)$. Unless stated otherwise all subsequent membrane fractions, from both rat and cow brain, were prepared in $50 \mathrm{mM} \mathrm{Na}$-phosphate buffer, pH 6.5.

(b) PCMT acting on endogenous MAPs. A comparison of the specific activities of PCMT acting on endogenous MAPs vs exogenous ovalbumin in rat cerebral cortex and cerebellum is shown in Table 1. Significant increases were noted in the presence of ovalbumin in each fraction, yet the magnitude of the increase was clearly lower in the two membrane fractions than in the $100,000 \mathrm{~g}$ supernatant. Since, on the other hand, the specific activity of PCMT in fraction $P_{1}$ was invariably higher than in the highspeed pellet $P_{T}$, we chose fraction $P_{1}$ for all further work, albeit modifying the centrfugation scheme slightly by washing pellet $P_{1}$, obtained at $17,500 \mathrm{~g}$, instead of $10,000 \mathrm{~g}$, with $50 \mathrm{mM} \mathrm{Na}$ phosphate buffer, $\mathrm{pH} 6.5$ for the number of times indicated in the appropriate table legends.

(c) The effects of $S A M$ and $S A H$. Figure 1 shows the [SAM] dependence of the truly cytosolic PCMT $\left[100,000 \mathrm{~g}\right.$ for $\left.60 \mathrm{~min},\left(\mathrm{~S}_{\mathrm{S}}\right)\right]$, the Lubrol-P $\mathrm{P}_{\mathrm{x}}$-solubilized $\operatorname{PCMT}\left(\mathrm{S}_{\mathrm{L}}\right)$ and the Lubrol- $\mathrm{P}_{\mathrm{x}}$-resistant PCMT $\left(\mathrm{P}_{\mathbf{L}}\right)$. Figure $1 \mathrm{~A}$ refers to the PCMT activity acting on ovalbumin and Fig. $1 \mathrm{~B}$ to that acting on the endogenous mb-MAPs. It may be seen that in all 3 fractions PCMT carboxylmethylated ovalbumin at a rapid rate and without approaching saturation, given the large excess of ovalbumin; conversely, PCMT appeared to reach saturation well within the range of the SAM concentrations when tested against endogenous MAP substrates, in both fractions $P_{L}$ and $S_{L}$. This resulted in MAP carboxylmethylation maxima of about 3 and $10 \mathrm{pmol} / \mathrm{mg}$ in fractions $\left(\mathrm{P}_{\mathrm{L}}\right)$ and $\left(\mathrm{S}_{\mathrm{L}}\right)$, respectively.

Inhibition of the mb-PCMT by SAH was compared by assaying the activity acting on added MAPs in the presence of $10^{-4}-10^{-7} \mathrm{MSAH} \pm 1 \%$ Lubrol$P_{x}$. The following $\%$ inhibitions were noted in the absence of the detergent: $23 \%$ at $10^{-7} \mathrm{M} \mathrm{SAH}$ and

Table 1. The PCMT activity acting on endogenous and added MAPs in centrifugal fractions of rat cerebrum and cerebellum

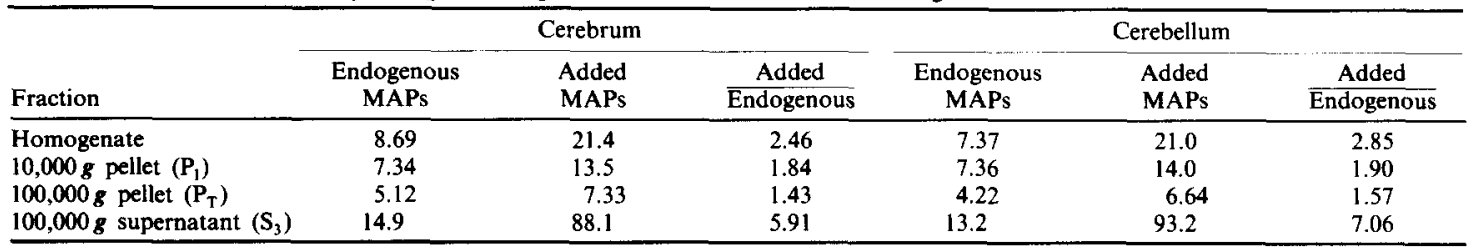

Values are in picomoles of $\left[{ }^{3} \mathrm{H}\right]$ methyl/mg protein. Added MAP: Ovalbumin, $10 \mu \mathrm{g} /$ tube. 
below $40 \%$ at $10^{-4} \mathrm{M} \mathrm{SAH}$; in the presence of the detergent, inhibition increased from $29 \%$ at $10^{-7} \mathrm{M}$ to $90 \%$ at $10^{-4} \mathrm{M} \mathrm{SAH}$. These findings strongly suggest that SAH has poor access to embedded mbMAPs in the absence of Lubrol- $P_{x}$ and a relatively unencumbered access in its presence.

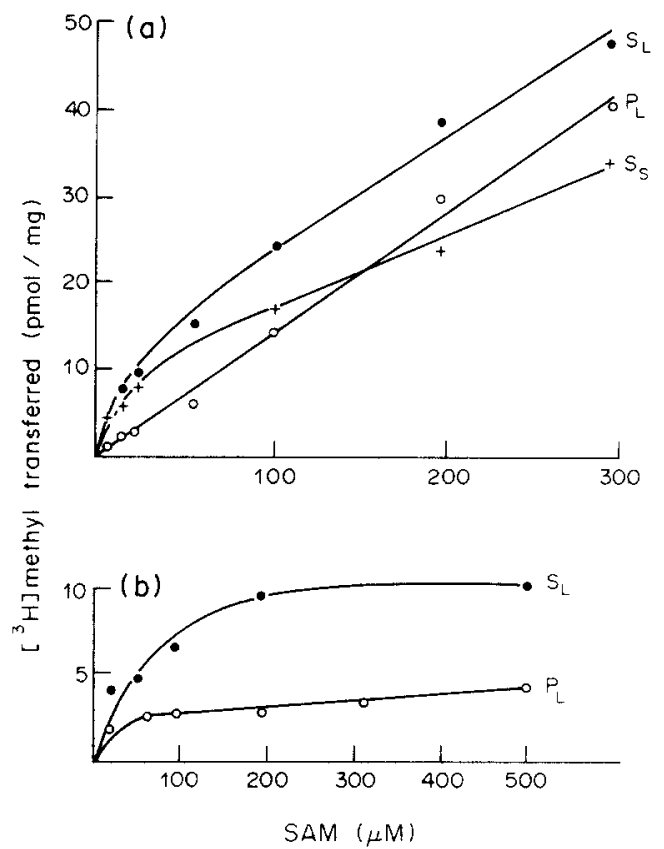

Fig. 1. The carboxyl- $\left[{ }^{3} \mathrm{H}\right]$-methylation of ovalbumin (A) and of endogenous brain membrane proteins $(B)$ by the cytosolic $\left(S_{S}\right)$, Lubrol- $P_{x}$-solubilized $\left(S_{L}\right)$ and Lubrol$\mathbf{P}_{\mathrm{x}}$-resistant $\left(\mathrm{P}_{\mathrm{L}}\right)$ forms of PCMT: Effect of S-adenosylL-methionine (SAM). (A). Cow cerebellum ( $3 \mathrm{~g}$ ) was homogenized in $40 \mathrm{ml}$ of $50 \mathrm{mM}$ Na-phosphate buffer $\mathrm{pH} 6.5$. Nine $\mathrm{ml}$ of the homogenate were centrifuged at $100,000 \mathrm{~g}$ for $60 \mathrm{~min}$ yielding the cytosol, $\mathrm{S}_{\mathrm{s}}$. The remaining $31 \mathrm{ml}$ were centrifuged at $1000 \mathrm{~g}$ for $10 \mathrm{~min}$. The supernatant was centrifuged at $17,500 \mathrm{~g}$ for $30 \mathrm{~min}$ and the resulting pellet was then washed and recentrifuged 6 times. Pellet No. 6 was homogenized in $7 \mathrm{ml}$ of $1 \%$ Lubrol- $P_{x}$ dissolved in buffer and the suspension was kept on ice for $30 \mathrm{~min}$. Centrifugation $(100,000 \mathrm{~g}, 60 \mathrm{~min})$ yielded pellet $P_{L}$, which was suspended in $5 \mathrm{ml}$ of Lubrol-buffer, and supernatant $S_{L}$. All fractions were assayed for PCMT activity (see Methods) for $30 \mathrm{~min}$ at $37^{\circ} \mathrm{C} . \mathrm{S}_{\mathrm{S}}$ : each tube contained $421 \mu \mathrm{g}$ of protein; $\mathrm{S}_{\mathrm{L}}$ : each tube contained $169 \mu \mathrm{g}$ of protein; $\mathrm{P}_{\mathrm{L}}$ : each tube contained $355 \mu \mathrm{g}$ of protein. (B) Cow cerebellum was processed as above in $A$, except that the buffer used up to and including the preparation of pellet No. 6 was $10 \mathrm{mM}$ Na-phosphate buffer, pH 6.8, containing a proteaseinhibitor cocktail, (see Methods). Pellet No. 6 was suspended in $50 \mathrm{mM}$ Na-phosphate buffer, pH 6.5 and the procedure outlined in $\mathrm{A}$ was then followed. Incubation to determine the PCMT activity was for $30 \mathrm{~min}$ at $37^{\circ} \mathrm{C}$ (see Methods). $\mathrm{S}_{\mathrm{L}}$ : each tube contained $203 \mu \mathrm{g}$ of protein; $\mathrm{P}_{\mathrm{L}}$ : each tube contained $416 \mu \mathrm{g}$ of protein.
The mb-PCMT in neuronal perikarya, astrocytes, oligodendroglia and synaptosomes

Neuronal perikarya, astrocytes and oligodendroglia were prepared (see Methods) and their PCMT activity determined. To obtain the cytosol and membrane fractions, the cellular preparations were homogenized in hypotonic medium and centrifuged at $100,000 \mathrm{~g}$ for $60 \mathrm{~min}$. PCMT acting on endogenous synaptic MAPs was determined in isotonic $0.32 \mathrm{M}$ sucrose and in 1\% Nonidet P-40. While the isotonic condition measured the PCMT activity associated with the outside surface of the synaptosome, total PCMT activity, including the intrasynaptosomal and the synaptic membrane-bound components, was being determined in the presence of the detergent. Table 2 reveals the ubiquitous presence of the PCMT acting on endogenous MAPs in all cellular and organelle preparations and in the cytosol and membranes prepared therefrom. As expected, the activity of the PCMT acting on added MAPs was uniformly higher. However, the increase was greater in the neuronal and astrocytic than in the oligodendroglial cytosol and smaller in the neuronal and astrocytic, than in the oligodendroglial, membranes. We also noted a greater than 7 -fold increase in the PCMT activity of total synaptosomes in the presence of Nonidet P-40; This increase became greatly reduced (to $c$. 2-fold over controls) when tested in the synaptic membranes.

\section{Solubilization of $m b-P C M T$}

(a) The effect of repeated washing and of detergents. To assess the nature of the structural association of mb-PCMT, the $17,500 \mathrm{~g}$ pellet (in $50 \mathrm{mM} \mathrm{NaPO}_{4}$ buffer, $\mathrm{pH}$ 6.5) was washed once, the resulting pellet No. 1 was resuspended and the suspension centrifuged at $17,500 \mathrm{~g}$ for $30 \mathrm{~min}$. This was repeated 5 successive times, yielding pellet No. 6 (Table 3, Al). Mb-PCMT acting on added MAPs (ovalbumin) represented $47.8 \%$ of the total activity in pellet No. 1 and $81.9 \%$ in pellet No. 6 . Three aliquots of pellet No. 6 were suspended in $1 \% \mathrm{Na}$-deoxycholate (D), $1 \%$ Nonidet $\mathrm{P}-40(\mathrm{~N})$ and $50 \mathrm{mM}$ phosphate buffer (B). After $30 \mathrm{~min}$ at $0^{\circ} \mathrm{C}$, centrifugation at $100,000 \mathrm{~g}$ for 30 min yielded pellets and supernatants No. 7(B), (D) and (N). As shown in Al the recoveries, relative to the respective parent pellets, were only slightly above $100 \%$ throughout the buffer-washing procedure. However. as shown in the legend to Table 3, A2, the PCMT activity of the high-speed supernatants $7(\mathrm{D})$ and $7(\mathrm{~N})$ was 3-5 times higher than the PCMT activity of supernatant $7(\mathbf{B})$, suggesting its activation upon being detergent-solubilized. Yet the 
Table 2. Protein carboxylmethyltransferase (PCMT) activity in neurons, glia and synaptosomes

\begin{tabular}{|c|c|c|c|c|c|c|}
\hline \multirow[b]{2}{*}{ Cell or Cell Component } & \multicolumn{2}{|c|}{ Total PCMT } & \multicolumn{2}{|c|}{ Membrane-bound PCMT } & \multicolumn{2}{|c|}{ Cytosolic PCMT } \\
\hline & $\begin{array}{c}\text { Endogenous } \\
\text { MAPs }\end{array}$ & $\begin{array}{l}\text { Added } \\
\text { MAPs }\end{array}$ & $\begin{array}{c}\text { Endogenous } \\
\text { MAPs }\end{array}$ & $\begin{array}{l}\text { Added } \\
\text { MAPs }\end{array}$ & $\begin{array}{c}\text { Endogenous } \\
\text { MAPs }\end{array}$ & $\begin{array}{l}\text { Added } \\
\text { MAPs }\end{array}$ \\
\hline Neuronal Perikarya & 6.0 & 13.6 & 4.1 & 6.7 & 19.5 & 50.6 \\
\hline Astrocytes & 2.6 & 5.8 & 1.9 & 3.6 & 3.4 & 13.2 \\
\hline Oligodendroglia & 11.7 & 18.4 & 9.2 & 21.4 & 57.2 & 87.4 \\
\hline Synaptosomes in $0.32 \mathrm{M}$ Sucrose & 2.4 & - & 13.7 & - & - & - \\
\hline Synaptosomes in $1 \%$ Nonidet P-40 & 17.8 & - & 30.2 & $\ldots$ & - & - \\
\hline
\end{tabular}

Values are in picomoles of $\left[{ }^{3} \mathrm{H}\right]$ methyl/mg protein. The recovery of PCMT activity and of protein between the membrane-bound and the cytosolic fractions was quantitative. The values are from one representative preparation of each cell type. These values were reproduced within $25 \%$ in 4 additional isolation runs for each cell type. The synaptosomal values, averages of 2 experiments, matched within $15 \%$.

PCMT activity in the detergent-resistant pellets $7(\mathrm{~B})$, $7(\mathrm{D})$ and $7(\mathrm{~N})$ was virtually identical (see legend, Table 3, A2). Table 3,B illustrates the effect of the agents listed on the PCMT activity of brain membranes in pellet No. 2. PCMT was not solubilized by $1 \mathrm{M} \mathrm{KCl}$; it was partially solubilized by $0.2 \%$ Na-deoxycholate, yet the solubilized form did not appear activated, as was noted after $1 \%$ Na-deoxycholate and 1\% Nonidet P-40 (see Table 3, A2 legend). The mb-PCMT was also effectively solubilized by $1 \%$ Lubrol- $\mathrm{P}_{x}$, yet with only a moderate activation of the solubilized activity.

(b) The effect of detergents on the specific activity of PCMT. Five pellets No. 6 (see Table 3, A1) were suspended in buffer and to each suspension was added sufficient detergent to achieve the indicated final concentrations (Table 4). After $30 \mathrm{~min}$ at $0^{\circ} \mathrm{C}$, the suspensions were centrifuged at $78,000 \mathrm{~g}$ for

Table 3. Effects of repeated washes, salt and detergent treatments of brain membranes on the solubilization of the membrane-bound PCMT

\begin{tabular}{|c|c|c|c|c|c|}
\hline & \multirow[b]{2}{*}{$\begin{array}{c}\text { Buffer* } \\
\text { wash No. }\end{array}$} & \multirow[b]{2}{*}{$\begin{array}{c}\text { Pellet } \\
\text { No. }\end{array}$} & \multicolumn{3}{|c|}{ Protein carboxylmethyltransferase (PCMT) } \\
\hline & & & $\begin{array}{c}P \\
(\%)\end{array}$ & $\begin{array}{c}S \\
(\%)\end{array}$ & $\begin{array}{c}\text { Recovery } \\
(\%)\end{array}$ \\
\hline \multicolumn{6}{|c|}{$A 1$} \\
\hline & 0 & $1 \dagger$ & 47.8 & 52.2 & 100 \\
\hline & 1 & 2 & 45.9 & 54.1 & 134 \\
\hline & 2 & 3 & 56.3 & 43.7 & 116 \\
\hline & 3 & 4 & 70.9 & 29.1 & 127 \\
\hline & 4 & 5 & 71.8 & 28.2 & 114 \\
\hline & 5 & 6 & 81.9 & 18.1 & 110 \\
\hline \multicolumn{6}{|c|}{$A 2$} \\
\hline & 6 & $7(\mathrm{~B})++$ & 65.7 & 34.3 & 100 \\
\hline & 6 & $7(\mathrm{D}) \dagger+$ & 40.5 & 59.5 & 178 \\
\hline & 6 & $7(\mathrm{~N})+\dagger$ & 29.5 & 70.5 & 242 \\
\hline \multirow{2}{*}{\multicolumn{6}{|c|}{ Treatment }} \\
\hline & & & & & \\
\hline & Buffer* (B) & 2 & 55.7 & 44.3 & 100 \\
\hline & $\mathrm{I} \mathrm{M} \mathrm{KCl}$ & 2 & 55.4 & 44.6 & 102 \\
\hline & $0.2 \% \mathrm{Na}$-deoxycholate & 2 & 34.3 & 65.7 & 99 \\
\hline & $1 \%$ Lubrol $P_{x}$ & 2 & 26.5 & 73.5 & 143 \\
\hline
\end{tabular}

P: pellet; S: supernatant. PCMT assays contained ovalbumin, $10 \mu \mathrm{g} /$ tube.

*50 mM Na-phosphate, $\mathrm{pH} 6.5$.

†Represents $24-29 \%$ of the tissue PCMT and $55-69 \%$ of tissue protein

+ (B): buffer; (D): $1 \%$ Na-deoxycholate; (N): $1 \%$ Nonidet P-40.

$A 1$. Cow cerebellum $(1.75 \mathrm{~g})$ was homogenized in $21 \mathrm{ml}$ of $50 \mathrm{mM} \mathrm{Na}$-phosphate buffer, $\mathrm{pH} 6.5$ and the homogenate was centrifuged at $10,000 \mathrm{~g}$ for $20 \mathrm{~min}$. The pellet (No. 1) was resuspended in $10 \mathrm{ml}$ of buffer and the suspension recentrifuged for 25 min, yielding pellet No. 2. The supernatants were saved. The resuspension and recentrifugation was repeated 4 more times, except that $100,000 \mathrm{~g}$ for $30 \mathrm{~min}$ were employed; this yielded pellets and supernatants $3-6$. The values refer to the sum of the PCMT activities of $P_{n}+S_{n}$, where $n=1-6$. Recovery refers to the activities recovered in $P_{n+1}+S_{n+1}$, as \% of the activity in $P_{n}$. The PCMT activity of pellet No. 1 transferred $0.56 \mathrm{pmol}$ of $\left[{ }^{3} \mathrm{H}\right]$ methyl to ovalbumin in $30 \mathrm{~min}$

A2. Aliquots of a pellet No. 6 suspension $(2,3 \mathrm{ml})$ (see $A 1)$ in buffer were incubated as such (B) or in the presence of $1 \% \mathrm{Na}$-deoxycholate (D) or Nonidet P-40 (N) at $0^{\circ} \mathrm{C}$ for $30 \mathrm{~min}$. The suspensions were centrifuged at $100,000 \mathrm{~g}$ for $30 \mathrm{~min}$ and the pellets resuspended in buffer. PCMT activity was determined in the 3 pellet suspensions and supernatants. Recovery refers to the sum of the activity of pellet $7(B)+$ supernatant $7(B)=100 \%$. The following activities were determined (see Methods for definition of unit): P(B): $0.119 ; P(D): 0.131$; $\mathrm{P}(\mathrm{N}): 0.129 ; \mathrm{S}(\mathrm{B}): 0.062 ; \mathrm{S}(\mathrm{D}): 0.192$ and $\mathrm{S}(\mathrm{N}): 0.309$ pmoles of $\left[{ }^{3} \mathrm{H}\right] \mathrm{CH}_{3}$ transferred.

$B$. Cow cerebellum was homogenized as above in $A 1$ and pellet and supernatant No. 1 were obtained. The pellet was resuspended in $12 \mathrm{ml}$ of buffer and four $3 \mathrm{ml}$ aliquots were recentrifuged in individual tubes at $10,000 \mathrm{~g}$ for $25 \mathrm{~min}$, yielding 4 pellets No. 2. Each of these was resuspended in $9 \mathrm{ml}$ of solution, as indicated and was recentrifuged, after $30 \mathrm{~min}$ at $0^{\circ} \mathrm{C}$, at $100,000 \mathrm{~g}$ for $60 \mathrm{~min}$. PCMT activity was determined in the resulting pellets and supernatants. Recovery refers to the \% of the activity of pellet $2(B)+$ supernatant $2(B)=100 \%$ 
$90 \mathrm{~min}$. Each pellet was suspended in the homologous detergent at the concentration which led to its generation, permitting the assay of the solubilized and the detergent-resistant PCMT in the presence of identical detergent concentrations. Of the 4 detergents tested, Nonidet P-40 and Triton X-100 caused no changes in the specific activity of the mb-PCMT, while the zwitterionic CHAPS and the ionic Na-deoxycholate produced membrane pellets highly enriched in PCMT activity.

(c) The effect of temperature and of CHAPS. Solubilization of membrane-bound enzymes, receptors, etc. by detergents (Hjelmeland and Chrambach, 1984), proteases (Singh et al., 1985) and other suitable reagents, such as thiols (Hersh, 1985) has been carried out at temperatures ranging between $0^{\circ} \mathrm{C}$ and $37^{\circ} \mathrm{C}$. Since in preliminary experiments using the zwitterionic detergent CHAPS at $0^{\circ} \mathrm{C}$ it appeared possible to partially uncouple the solubilization of the mb-PCMT from that of the mb-MAPs, it became of interest to determine what effect temperature exerted on this process.

The effects of preincubating pellet No. 6 (see Table $3, \mathrm{Al}$ ) at $0^{\circ}, 25^{\circ}$ and $37^{\circ} \mathrm{C}$ in the presence and absence of $30 \mathrm{mM}$ CHAPS are shown in Table 5 . CHAPS appeared to stimulate the PCMT acting on

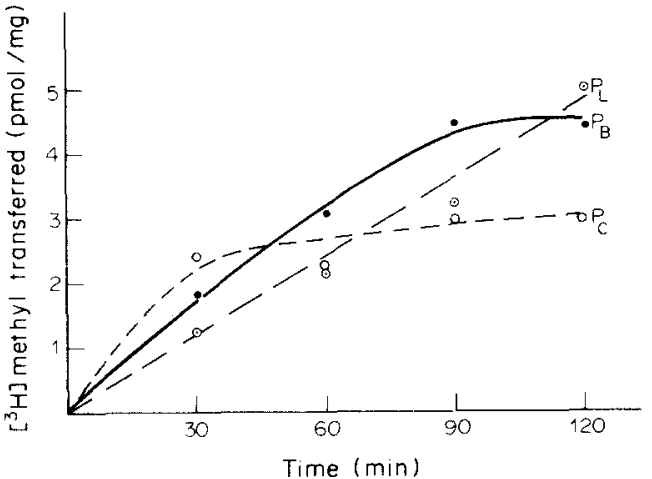

Fig. 2. The effect of exposure of cerebellar membranes to Lubrol- $P_{X}$ and CHAPS on the time course of PCMT activity. Three pellets No. 6, prepared from 3 pieces of cow cerebellum, weighing $2.9 \mathrm{~g}$ each, as described in Methods, were suspended in $5 \mathrm{ml}$ of $50 \mathrm{mM}$ Na-phosphate buffer, pH 6.5 (B), 1\% Lubrol- $\mathrm{P}_{\mathrm{x}}$ (L) and $30 \mathrm{mM}$ CHAPS (C) and the suspensions were kept on ice for $30 \mathrm{~min}$. Following $100,000 \mathrm{~g}$ for $60 \mathrm{~min}$, each pellet was resuspended in $5 \mathrm{ml}$ of buffer and aliquots of each suspension $\left(P_{B}, P_{1}\right.$ and $\left.P_{C}\right)$ were incubated to determine the PCMT activity in the absence of ovalbumin for the times indicated.

added MAPs, but not that acting on endogenous MAPs (column II vs I); this stimulation was maximal after preincubation of the membranes at $0 \mathrm{C}$. In the

Table 4. The effect of detergents on the specific activity of mb-PCMT

\begin{tabular}{llllllll}
\hline \multicolumn{2}{c}{ Na-deoxycholate } & \multicolumn{2}{c}{ Nonidet } & P-40 & \multicolumn{2}{c}{ Triton X-100 } & \multicolumn{2}{c}{ CHAPS } \\
\hline$\%$ & s.a.* & $\%$ & s.a. & $\%$ & s.a. & mM & s.a. \\
0 & 100 & 0 & 100 & 0 & 100 & 0 & 100 \\
0.2 & 189 & 0.2 & 108 & 0.05 & 117 & 2.5 & 102 \\
0.4 & 245 & 0.4 & 100 & 0.10 & 112 & 5.0 & 124 \\
0.75 & 304 & 0.8 & 115 & 0.25 & 97 & 10 & 155 \\
1.0 & 412 & 1.5 & 116 & 0.50 & 124 & 30 & 179 \\
\hline
\end{tabular}

*s.a. of PCMT in pellet No. 7 (see Table 3, A2), as $\%$ of the s.a. in the buffer-washed $(0 \%)$ pellet, set to $100 \%$

Brain was homogenized in $50 \mathrm{mM}$ Na-phosphate buffer, pH 6.5. except as indicated below, and pellet No. 6 was prepared as described in Methods after 4 successive washes of pellet No. 2 at $17,500 \mathrm{~g}$ for $30 \mathrm{~min}$. The pellet was resuspended in $10 \mathrm{ml}$ of $50 \mathrm{mM}$ buffer $(15 \mathrm{mM} \mathrm{Na}$ phosphate was used in the case of $\mathrm{Na}$-deoxycholate due to gelling in the $50 \mathrm{mM}$ buffer at the 0.75 and $1 \%$ concentrations at $0 \mathrm{C}$ ), and 5 two $\mathrm{ml}$ aliquots were apportioned to tubes which received buffer or detergent to reach the concentrations indicated. After $30 \mathrm{~min}$ at $0 \mathrm{C}$. the suspensions were centrifuged at $78,000 \mathrm{~g}$ for $90 \mathrm{~min}$ and the pellets resupended in buffer $(0 \%)$ or detergent, as indicated, for determination of PCMT activity in the presence of $10 \mu \mathrm{g}$ of ovalbumin.

Table 5. Effects of CHAPS and of temperature on the specific activity of PCMT

\begin{tabular}{|c|c|c|c|c|c|c|c|c|}
\hline \multirow{2}{*}{$\begin{array}{l}\text { Preincubation } \\
\text { temperature }\end{array}$} & \multicolumn{2}{|c|}{$\begin{array}{c}\text { I } \\
\text { Control membranes }\end{array}$} & \multicolumn{2}{|c|}{ Membranes + CHAPS } & \multicolumn{2}{|c|}{$\begin{array}{c}\text { III } \\
\text { CHAPS pellet }\end{array}$} & \multicolumn{2}{|c|}{$\begin{array}{c}\text { IV } \\
\text { CHAPS supernatant }\end{array}$} \\
\hline & (a) & (b) & (a) & (b) & (a) & (b) & (a) & (b) \\
\hline${ }^{\circ} \mathrm{C}$ & 5.51 & 6.50 & 5.00 & 12.5 & 21.6 & 26.7 & 58.3 & 156.2 \\
\hline $25 \mathrm{C}$ & 4.20 & 9.25 & 5.64 & 11.4 & 14.5 & 18.9 & 58.3 & 127.8 \\
\hline $37^{\circ} \mathrm{C}$ & 4.10 & 5.95 & 5.66 & 7.7 & 8.7 & 14.3 & 56.7 & 144.4 \\
\hline
\end{tabular}

Values are in picomoles $\left({ }^{3} \mathrm{H}\right]$ methyl/mg protein. (a): PCMT acting on endogenous MAPs; (b): PCMT acting on ovalbumin.

Preincubation of control membranes (I) (pellet No. 6, Table 3, A1) was in $8 \mathrm{ml}$ of $0.32 \mathrm{M}$ sucrose in $20 \mathrm{mM}$ Na-phosphate buffer, pH 6.5 . Membranes + CHAPS (II) ( $8 \mathrm{ml}$ ) contained $30 \mathrm{mM}$ CHAPS and were preincubated for $30 \mathrm{~min}$ at the temperatures indicated. Preparations (III) and (IV) were obtained by centrifugation of preparation II $(100,000 \mathrm{~g}, 60 \mathrm{~min})$. CHAPS pellets (III) were resuspended in $30 \mathrm{mM}$ CHAPS in $20 \mathrm{mM}$ Na-phosphate buffer, containing $0.32 \mathrm{M}$ sucrose. 
CHAPS pellet (column III vs II), the s.a. of the PCMT acting on endogenous MAPs increased by 3.9- and 2.1-fold and that of the enzyme acting on added MAPs by a closely similar 4.1- and 2.4-fold at $0^{\circ}$ and $37^{\circ} \mathrm{C}$, respectively. The s.a. of PCMT in the CHAPS supernatant (column IV) appeared largely independent of the temperature of preincubation, yet its absolute values exceeded those of the s.a. of PCMT in the CHAPS pellets (column IV vs III). Conversely, although the s.a. of PCMT in the CHAPS pellet was lowest following preincubation

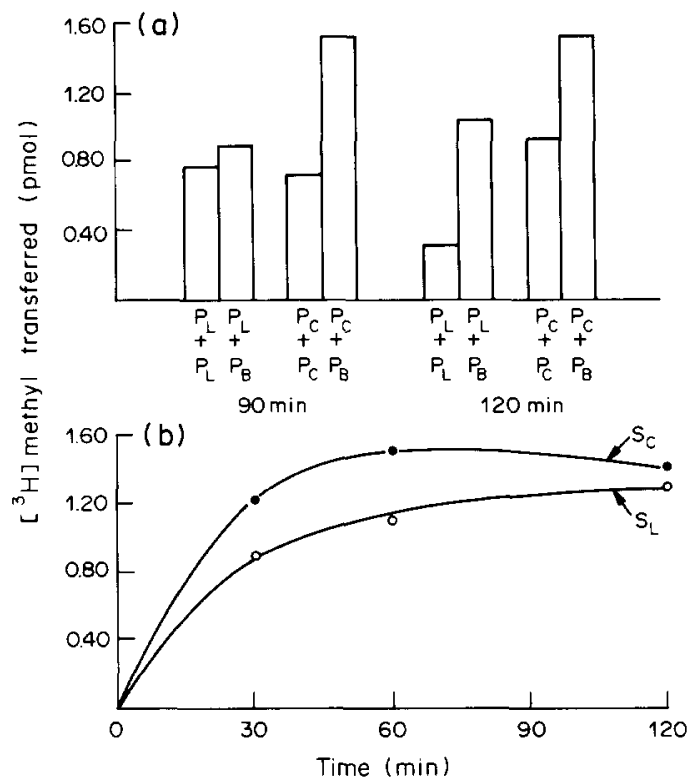

Fig. 3. (A). The effect of buffer (pH 6.5)-, Lubrol- $\mathrm{P}_{\mathrm{x}^{-}}$and CHAPS-treated mb-MAPs on PCMT acting on endogenous MAPs. Three pellets No. 6 were prepared, their suspensions exposed to $50 \mathrm{mM}$ Na-phosphate buffer, pH 6.5 (B), Lubrol- $\mathrm{P}_{\mathrm{x}}$ (L) and CHAPS (C) at $0^{\circ} \mathrm{C}$ for $30 \mathrm{~min}$ and the high-speed pellets obtained, as described in the legend to Fig. 2. Unlike in the experiment depicted in Fig. 2, however, the high-speed pellets were each suspended in the solution in which they were cold-exposed, yielding suspension $\mathrm{P}_{\mathrm{B}}, \mathrm{P}_{\mathrm{L}}$ and $P_{C}$. Aliquots $(200 \mu \mathrm{l})$ of these suspensions were placed to incubate in the PCMT assay medium and the mb-PCMT activity determined at 30 and $60 \mathrm{~min}$ (not shown). To parallel tubes, the following were added at $60 \mathrm{~min}: 200 \mu 1$ of $\mathrm{P}_{\mathrm{L}}$ and $200 \mu 1$ of $\mathrm{P}_{\mathrm{C}}$ and $200 \mu 1$ of $\mathrm{P}_{\mathrm{B}}$ to tubes containing suspension $\mathrm{P}_{\mathrm{L}}$ and $200 \mu 1$ of $\mathrm{P}_{\mathrm{B}}$ to tubes containing suspension $P_{C}$. These conditions are referred to in the figure as $\mathrm{P}_{\mathrm{L}}+\mathrm{P}_{\mathrm{L}}, \mathrm{P}_{\mathrm{L}}+\mathrm{P}_{\mathrm{B}}, \mathrm{P}_{\mathrm{C}}+\mathrm{P}_{\mathrm{C}}$ and $\mathrm{P}_{\mathrm{C}}+\mathrm{P}_{\mathrm{B}}$, respectively. $\mathrm{Mb}$ $P C M T$ activity was again determined 30 and 60 min later, i.e. 90 and $120 \mathrm{~min}$ after the start of the incubations: (B). The effect of Lubrol-P $P_{x}$ and CHAPS on the solubilized PCMT. The activity of PCMT was determined in the highspeed supernatants $\left(S_{L}\right.$ and $\left.S_{C}\right)$ obtained by centrifuging suspensions exposed to $1 \%$ Lubrol- $P_{x}$ and $30 \mathrm{mM}$ CHAPS for $30 \mathrm{~min}$ at $0^{\circ} \mathrm{C}$ (see legend, Fig. 2). at $37^{\circ} \mathrm{C}$, its absolute values exceeded those of the enzyme in the unfractionated membranes (column III vs II), under all conditions tested.

\section{Factors altering the $m b-M A P s$}

(a) Exposure to detergents. The following experiments were primarily designed to identify conditions which would alter the ability of the endogenous mb-MAPs to act as mb-PCMT substrates. In one experiment (Fig. 2), aliquots of a suspension of pellet No. 6 were preincubated at $0^{\circ} \mathrm{C}$ for $30 \mathrm{~min}$ in buffer, $1 \%$ Lubrol- $\mathrm{P}_{\mathrm{x}}$ and $30 \mathrm{mM}$ CHAPS, and a time course of PCMT activity was determined using high-speed pellet suspensions prepared in buffer. It may be noted that the brief exposure of the mb-MAP-PCMT system to the two detergents at $0^{\circ} \mathrm{C}$ resulted in significant differences between the $P_{L}$ and $P_{C}$ time courses. The action of CHAPS, relative to that of Lubrol- $\mathrm{P}_{\mathrm{x}}$, appeared to result in a doubling of the amount of mb-MAPs which could be carboxylmethylated in the initial $30 \mathrm{~min}$; yet, at the end of the 120 min incubation period, the carboxylmethylation of the Lubrol- $P_{x}$ treated MAPs matched that of the buffer-treated controls, while that of the CHAPStreated MAPs still proved inferior. These apparently different effects of Lubrol-Px and CHAPS on the ability of mb-MAPs to act as endogenous substrates of the mb-PCMT were further assessed in another experiment in which Lubrol- $\mathrm{P}_{\mathrm{x}}$ and CHAPS pellets were resuspended not in buffer, as above, but in $1 \%$ Lubrol- $\mathrm{P}_{\mathrm{x}}$ and $30 \mathrm{mM}$ CHAPS and were then placed to incubate in the PCMT assay medium at $37^{\circ} \mathrm{C}$ (Fig. 3A). After $60 \mathrm{~min}, 200 \mu 1$ aliquots of the coldpreincubated, detergent- or buffer-containing suspensions of MAPs were added and incubation continued for an additional $60 \mathrm{~min}$ at $37^{\circ} \mathrm{C}$. Figure $3 \mathrm{~A}$ shows that the addition of the buffer-suspended MAPs to the detergent-treated membrane suspensions led to markedly higher PCMT activities than were obtained by adding to them detergent-suspended MAPs. Conversely, the time course of the detergentsolubilized PCMT acting on the equally solubilized endogenous MAPs (Fig. 3B) reflects comparable effects of the two detergents on this form of the enzyme.

(b) Effect of $p H$, buffer species and detergent. We also compared the specific activity of PCMT acting on endogenous MAPs in $20 \mathrm{mM}$ Tris-citrate and MOPS buffers at pH 6.5 and in $20 \mathrm{mM}$ MES buffer at pH 5.5 in the absence and presence of $0.1 \%$ Nonidet P-40. Increases in enzyme activity of 3.5-, 2.2- and 1.4-fold over controls were noted in the detergent's presence (data not shown). 
Table 6. The carboxyl- $\left[{ }^{3} \mathrm{H}\right]$ methylation of purified proteins by the mb-protein carboxylmethyltransferase (PCMT)

\begin{tabular}{clc}
\hline $\begin{array}{c}\text { Experiment } \\
\text { No. }\end{array}$ & \multicolumn{1}{c}{ Addition } & $\begin{array}{c}{\left[{ }^{3} \mathrm{H}\right] \text { methyl }} \\
\text { transferred } \\
\text { (pmol) }\end{array}$ \\
\hline 1. & None* & 3.29 \\
& + ovalbumin, $10 \mu \mathrm{g}$ & 7.79 \\
& + synapsin, $5 \mu \mathrm{g}$ & 5.11 \\
& + synapsin, $10 \mu \mathrm{g}$ & 9.44 \\
2. & Nonet & 3.41 \\
& + ovalbumin, $10 \mu \mathrm{g}$ & 5.15 \\
& + calmodulin, $5 \mu \mathrm{g}$ & 5.05 \\
3. & Noneł & 12.5 \\
& + BSA, 100 $\mu \mathrm{g}$ & 21.3 \\
& +ovalbumin, $10 \mu \mathrm{g}$ & 33.0 \\
\hline
\end{tabular}

*mb-PCMT from neuronal microsomes (Sellinger and Santiago. 1972), $3.51 \mu \mathrm{g}$ of protein.

$\dagger$ Pellet No. 6 membranes (see Table 3, A1), $0.50 \mathrm{mg}$ of protein. ‡ Pellet No. 3 membranes (see Table $3, \mathrm{Al}$ ), $0.92 \mathrm{mg}$ of protein. The PCMT assay volume was $255 \mu \mathrm{l}$ (see Methods).

(c) Purified proteins as substrates for the $m b$ $P C M T$. Ovalbumin, BSA, calmodulin and synapsin were compared. The results of experiments (1) and (2) (Table 6) demonstrate that the mb-PCMT of rat brain recognizes $5-10 \mu \mathrm{g}$ of synapsin and $5 \mu \mathrm{g}$ of calmodulin somewhat more effectively than $10 \mu \mathrm{g}$ of ovalbumin, while experiment No. 3 reveals that BSA is a much poorer substrate for the mb-PCMT than ovalbumin.

(d) The effect of $\mathrm{NH}_{4} \mathrm{OH}$. Recently, treatment of the purified protein calmodulin with $0.1 \mathrm{M} \mathrm{NH}_{4} \mathrm{OH}$ was shown to result in a substantial increase in its carboxylmethylation by the cytosolic type I isozyme of bovine brain PCMT (Aswad and Deight, 1983b). As shown in Table 7, we tested the effectiveness of this mild alkaline treatment on the generation of new carboxylmethylatable sites in brain MAPs by treating
Table 7. Mild alkaline treatment of detergent-solubilized brain MAPs greatly increases their carboxyl- $\left[{ }^{3} \mathrm{H}\right]$ methylation by the equally detergent-solubilized PCMT.

\begin{tabular}{lccc}
\hline \multicolumn{1}{c}{ Treatment } & $\begin{array}{c}\text { Protein } \\
(\mu \mathrm{g})\end{array}$ & $\begin{array}{c}{\left[{ }^{3} \mathrm{H}\right]-\mathrm{MAPs}} \\
(\mathrm{pmol} / \mathrm{mg})\end{array}$ & $\begin{array}{c}\Delta, \mathrm{NH}_{4} \mathrm{OH} \\
\%\end{array}$ \\
\hline $\begin{array}{l}\text { Lubrol- } \boldsymbol{P}_{x} \\
\quad \text { Control }\end{array}$ & 613 & & \\
$\quad+0.05 \mathrm{M} \mathrm{NH}_{4} \mathrm{OH}$ & 582 & 37.8 & - \\
$\quad \begin{array}{l}\text { Nonidet } P-40 \\
\text { Control }\end{array}$ & & & +405 \\
$\quad+0.05 \mathrm{M} \mathrm{NH}_{4} \mathrm{OH}$ & 616 & 10.9 & - \\
\hline
\end{tabular}

Brain membranes contained in pellet No. 6 (see, Table 3, A1) were suspended in $5 \mathrm{ml}$ of $1 \%$ Lubrol- $\mathrm{P}_{\mathrm{x}}$ or Nonidet P-40. The resuspensions were kept on ice for $30 \mathrm{~min}$ and were centrifuged for $30 \mathrm{~min}$ at $17,500 \mathrm{~g}$. Duplicate $400 \mu 1$ aliquots of each supernatant were mixed with either $40 \mu \mathrm{l}$ of $0.55 \mathrm{M} \mathrm{Na}$-phosphate buffer, $\mathrm{pH} 6.6$ (control) or $40 \mu \mathrm{l}$ of $0.55 \mathrm{M} \mathrm{NH}_{4} \mathrm{OH}$ and were preincubated at $37^{\circ} \mathrm{C}$ for $90 \mathrm{~min}$. The $\mathrm{pH}$ of all samples was adjusted to 6.5 and $220 \mu \mathrm{l}$ aliquots, containing the amounts of protein indicated, were then transferred to tubes containing $45 \mu 1$ of the ovalbumin-free PCMT assay medium. Incubation was for $30 \mathrm{~min}$ at $37^{\circ} \mathrm{C}$.

the Nonidet $\mathrm{P}-40$ and the Lubrol- $\mathrm{P}_{\mathrm{x}}$ supernatants derived from pellet No. 6 (see Table $3, \mathrm{~A} 1$ ) with $\mathrm{NH}_{4} \mathrm{OH}$ for $90 \mathrm{~min}$ at $37^{\circ} \mathrm{C}$. However, because we found $0.1 \mathrm{M} \mathrm{NH}_{4} \mathrm{OH}$ to severely inactivate the solubilized PCMT, the concentration of $\mathrm{NH}_{4} \mathrm{OH}$ was lowered to $0.05 \mathrm{M}$. The alkaline treatment led to 3.6-4.0-fold elevations in carboxylmethylation of the detergent solubilized MAPs by an apparently alkaliresistant and largely unscathed PCMT (Kim, 1984).

(e) The combined $\mathrm{BTI}+\mathrm{NH}_{4} \mathrm{OH}$ pretreatment. The protein modifying reagent BTI (see Materials) which converts the carboxyamide group of protein asparagine to the corresponding primary amine (Soby and Johnson, 1981; Johnson et al., 1985), was incubated with a Lubrol- $\mathrm{P}_{\mathrm{x}}$ solubilized extract of pellet No. 6 (see Table $3 \mathrm{~A}, 1)(1.36 \mathrm{mg}$ of protein) in a volume of

Table 8. Effect of BTI pretreatment on the $\mathrm{NH}_{4} \mathrm{OH}$-induced methyl accepting capacity of Lubrol- $P_{\mathrm{x}}$ - solubilized rat brain MAPs.

\begin{tabular}{|c|c|c|c|}
\hline $\begin{array}{l}\text { First preincubation } \\
\left(60^{\circ} \mathrm{C}\right) \text {, in: }\end{array}$ & $\begin{array}{l}\text { Second preincubation } \\
\left(37^{\circ} \mathrm{C}\right) \text {, in: }\end{array}$ & \multicolumn{2}{|c|}{$\begin{array}{c}{\left[{ }^{3} \mathrm{H}\right] \text { methyl transferred }} \\
\text { to MAPs (pmol) }\end{array}$} \\
\hline 1. Buffer* & Buffer & $\begin{array}{c}\text { Uncorrected } \\
58.7\end{array}$ & Corrected \\
\hline 2. $\mathrm{DMF}+\mathrm{TFA}^{+}$ & Buffer & 28.7 & $\ldots$ \\
\hline 3. BTIt+ in DMF + TFA & Buffer & 43.2 & 14.5 \\
\hline 4. as in 2 . & $\mathrm{NH}_{4} \mathrm{OH}, 0.05 \mathrm{M}$ & 90.3 & 61.6 \\
\hline 5. as in 3 . & $\mathrm{NH}_{4} \mathrm{OH}, 0.05 \mathrm{M}$ & 74.7 & 31.5 \\
\hline
\end{tabular}

*Buffer: $50 \mathrm{mM}$ Na-phosphate, $\mathrm{pH}$ 6.5; †DMF: dimethylformamide; TFA: trifluoroacetic acid; †+BTI: bis(I,I-trifluoroacetoxy)-iodobenzene.

The basal conditions describing this experiment were taken from Johnson et al. (1985). Further details are listed in Methods and text. The source of MAPs was the $17,500 \mathrm{~g}$ $(30 \mathrm{~min}$ ) supernatant derived from a $30 \mathrm{~min}(0 \mathrm{C})$ treatment of pellet No. 6 (see Table 3. Al) with $1 \%$ Lubrol-P ${ }_{x}$. Following the first preincubation (BTI: $36 \mathrm{mg} ; 60 \mathrm{C}, 4 \mathrm{~h}$ in the dark), dialysis, the second preincubation $\left(377^{\prime \prime} \mathrm{C}, 90 \mathrm{~min}\right)$ and $\mathrm{pH}$ adjustment to 6.5 , an identical amount of protein $(0.271 \mathrm{mg})$ was incubated in the presence of $20 \mu \mathrm{l}$ of the purified cytosolic rat brain PCMT and MAP capacity was determined The corrected picomole values were obtained by subtracting (2) from (3), (2) from (4) and (3) from (5). 
$1 \mathrm{ml}$ in the dark for $4 \mathrm{~h}$ at $60^{\circ} \mathrm{C}$, with appropriate controls incubated alongside (lines 2 and 3). All samples were then dialysed overnight against distilled water and were preincubated for $90 \mathrm{~min}$ at $37^{\circ} \mathrm{C}$ either in the presence of $50 \mathrm{mM}$ Na phosphate buffer, pH 6.5 or of $0.05 \mathrm{M} \mathrm{NH}_{4} \mathrm{OH}$. Samples were then adjusted, as required, to $\mathrm{pH} 6.5$ with $1 \mathrm{M}$ acetic acid.
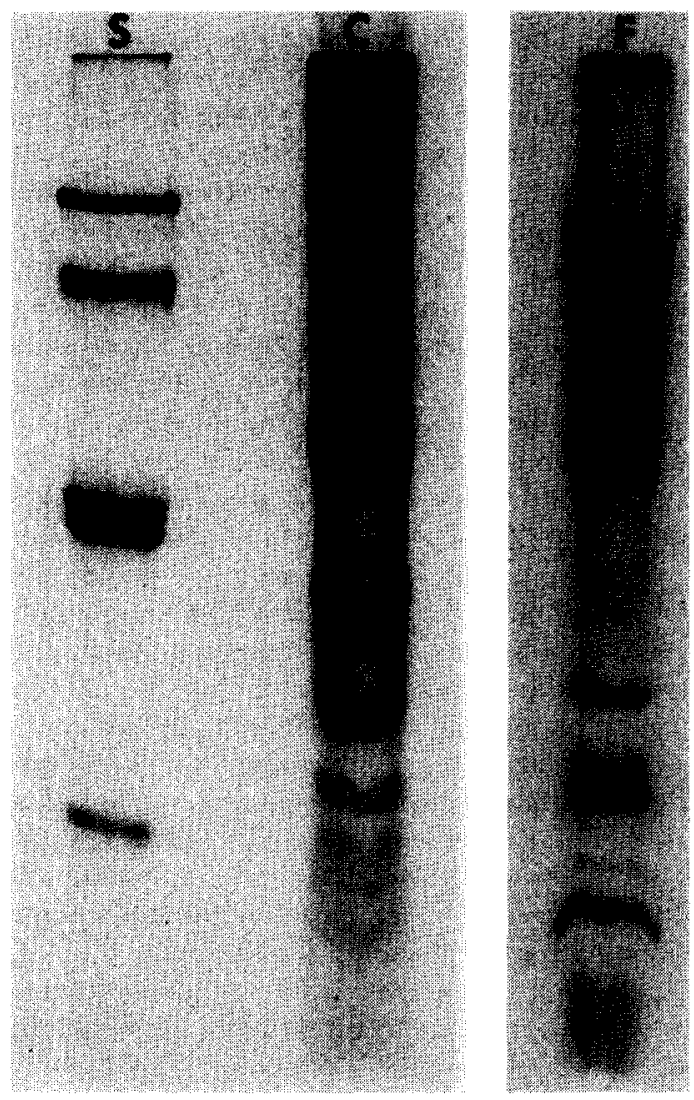

Fig. 4. Acidic slab gel electrophoresis of the endogenous carboxyl- $\left[{ }^{3} \mathrm{H}\right]$-methylated rat brain membrane-bound proteins. Pellet No. 6 (see legend to Table $3 \mathrm{~A})(1.3 \mathrm{mg}$ of protein) was subjected to carboxyl- $\left[{ }^{3} \mathrm{H}\right]-$ methylation, as described in Methods, for $2 \mathrm{~h}$ at $37^{\circ} \mathrm{C}$, in the presence of $20 \mu$ curies of $\left[{ }^{3} \mathrm{H}\right]$-methyl SAM $(19 \mathrm{Ci} / \mathrm{mmol})$. Pellets were obtained by centrifugation $(6,000 \mathrm{rpm}, 30 \mathrm{~min})$ and after one wash were resuspended in $300 \mu$ l of acidic sample buffer (Aswad and Deight, 1983a). Sixty-nine $\mu$ l, containing $300 \mu \mathrm{g}$ of protein/lane, was applied. Lane S: molecular weight standards, from the top down: phosphorylase $b$ (94 KDa); bovine serum albumin $(67 \mathrm{KDa})$; ovalbumin ( $43 \mathrm{KDa})$; carbonic anhydrase $(30 \mathrm{KDa}$ but, in confirmation of Aswad and Deight (1983a), running in this gel system as a $40 \mathrm{KDa}$ protein) and soybean trypsin inhibitor (20.1 KDa), Lane C: Coomassie blue staining pattern of pellet No. 6 proteins; Lane F: $\left[{ }^{3} \mathrm{H}\right]$-fluorogram of the carboxyl- $\left[{ }^{3} \mathrm{H}\right]$-methylated pellet No. 6 proteins.
For the subsequent determination of MAPs, the carboxyl- $\left[{ }^{3} \mathrm{H}\right]-$-methylation assay was fortified by the addition of $20 \mu 1$ of the purified, cytosolic rat brain PCMT (see Materials). All tubes contained an identical amount of protein $(0.271 \mathrm{mg})$. The results show an apparent effect of BTI per se, relative to the control containing the acidic solvent alone (compare lines 3 and 2), on the generation of carboxyl- $\left[{ }^{3} \mathrm{H}\right]-$ methylatable sites; we have no cogent explanation for this observation, which we have made repeatedly. However, the principal feature of the findings shown in Table 8 is the marked reduction of the ability of $\mathrm{NH}_{4} \mathrm{OH}$ to generate new MAP sites for PCMT action, following BTI treatment (compare corrected values in lines 5 and 4). This finding, replicated in 3 consecutive experiments, is consistent with the notion that BTI converts a portion of MAP amide residues, such as those present in glycine-linked asparagines (Johnson et al., 1985), to the corresponding primary amines, thus rendering them unavailable for the subsequent $\mathrm{NH}_{4} \mathrm{OH}$-induced conversion to novel carboxyl $-\left[{ }^{3} \mathrm{H}\right]$-methylatable sites.

(f) The nature of the $m b-M A P s$. The results of acidic slab gel electrophoresis of the carboxyl$\left[{ }^{3} \mathrm{H}\right]$-methylated mb-MAPs are illustrated in Fig. 4, together with a Coomassie Blue staining profile of the proteins present in the membranes contained in pellet No. 6. The figure illustrates the fact that relatively few membrane proteins appear to act as MAPs for the mb-PCMT, and that fewer than a dozen, ranging in molecular weights from under 20 to about $90 \mathrm{KD}$, share the greater portion of the radioactivity associating with the mb-carboxyl $-\left[{ }^{3} \mathrm{H}\right]$ methylated proteins.

\section{DISCUSSION}

The present findings aim to characterize the mbprotein carboxyl-methylation system of brain tissue and constitute evidence for its association with membranes of all 3 principal cell types of rat brain, namely the neurons, the glial astrocytes and the oligodendroglial cells. In addition, the findings emphasize the self-sufficiency of the mb-protein carboxylmethylation system under study, in that they show a selective capacity of some, but not all of the mb-proteins, to act as MAPs for mb-PCMT (Fig. 4). The findings thus greatly expand the observations of Diliberto and Axelrod (1976), who first noted the existence of "endogenous" protein carboxylmethylation in brain tissue and those of Iqbal and Steenson (1976), who first documented the fact that cerebellar membranes contain PCMT activity able to recognize exogenously 
added MAPs. It is indeed important to point out that since brain mb-PCMT activity has so far been assayed exclusively in the presence of added MAPs, no information on its intrinsic ability to use endogenous mb-MAPs as its effective and specific substrates has been presented to date.

Recently, Brown (1984) reported that the PCMT activity associated with whole rat brain synaptosomes, isolated on sucrose-density gradients, became non-sedimentable after exposure to $0.2 \%$ Triton $\mathrm{X}$ 100 at $37^{\circ} \mathrm{C}$ for $30 \mathrm{~min}$ and high-speed centrifugation. Brown (1984) also reported activity ratios between the PCMT acting on added vs endogenous MAPs of about 3 for total synaptosomes. We report values approximating 7 (Table 2) in synaptosomes isolated on Percoll-gradients. Our data also reveals (Table 2) a doubling of the activity of synaptosomal mbPCMT acting on endogenous MAPs when assayed in the presence of $1 \%$ Nonidet P-40, a finding suggesting a topographic location for the mb-PCMT-MAP system deep within the matrix of the synaptic membrane. The presence of such an mb-PCMT component in synaptic membranes could not be inferred from the published literature to date (Diliberto and Axelrod, 1976; Brown, 1984).

The presence of PCMT activity in homogenates, membranes and cytosolic fractions derived from glial cells is also reported in Table 2. These findings document an extraneuronal localization for brain protein carboxylmethylation and point to a quantitatively significant activity in the oligodendroglial cells. Since bovine and rat myelin and bovine basic myelin protein have recently been shown to be excellent substrates for cytosolic PCMT (Johnson and Aswad, 1985a), the present findings are not overly surprising. They also cast doubt on the notion of a special role of protein carboxylmethylation in brain areas abounding in specialized neuronal elements (Billingsley and Lovenberg, 1985; Billingsley et al., 1985a; Billingsley and Balaban, 1985).

As previously noted with cerebral mb-catecholO-methyltransferase (Jeffery and Roth, 1984), the PCMT activity of pellet No. 1 (Table 3, A1) accounted for no more than $30 \%$ of the total PCMT; moreover, it resisted solubilization more effectively with successive buffer washes until, after wash No. 5 , only $18.1 \%$ if its residual mb-activity became nonsedimentable. Treatment of the membranes in pellet No. 6 with detergents resulted in effective solubilization of PCMT as well as in a major "activation" of the solubilized enzyme (Table 3, A2) as evidenced by its excessive recoveries after $1 \% \mathrm{Na}$-deoxycholate, $1 \%$ Nonidet $\mathrm{P}-40$ and $1 \%$ Lubrol- $\mathrm{P}_{\mathrm{x}}$
The more detailed study of the differential sensitivity of the mb-PCMT activity toward detergents (Table 4) revealed that its exposure to Na-deoxycholate and, to a lesser extent, CHAPS, led to significant stimulation of mb-PCMT acting on added MAPs, while a similar exposure to Triton X-100 and Nonidet P-40 had no such effect. Different effects of detergents on mb-brain enzymes have been reported (Percy et al., 1982; Singh et al., 1985), and it is of particular interest that Na-deoxycholate, which markedly stimulates mb-PCMT (Table 4), was shown to totally inhibit the phospholipid methyltransferase activities in brain membranes (Percy et al., 1982).

In an attempt to determine whether the stimulation of the mb-PCMT activity by CHAPS at $0^{\circ} \mathrm{C}$ (Table 4) could be modulated by raising the temperature, the experiment described in Table 5 was performed. Comparison of the effect of temperature on the s.a. of the mb-PCMT acting on endogenous MAPs reveals its decrease in the absence, and its slight increase in the presence of CHAPS (II vs I). Table 5 also shows that the s.a. of the CHAPSresistant mb-PCMT component decreased markedly as a function of the temperature of preincubation, while, conversely, the s.a. of the CHAPS-solubilized PCMT underwent no such temperature-dependent decrease. The overall findings of Table 5 reflect a complex response of the mb-PCMT component to the dual challenge of temperature and $30 \mathrm{mM}$ CHAPS. Whether this response is in turn a manifestation of the existence of the mb-PCMT as a glycosylated (Sweetnam and Tallman, 1986), or otherwise post-translationally modified, membrane-integral protein cannot be answered at this time.

The nature of the mb-MAPs was investigated in several ways, by examining effects of detergents on their quality as mb-PCMT substrates (Figs 2 and 3) and by chemically modifying them (Tables 7 and 8). This was done in an attempt to learn more about the structural requirements necessary for a protein to act as an effective substrate for endogenous mb-PCMT. We also confirmed that purified proteins which are excellent MAPs for the cytosolic PCMT (Gagnon et al., 1981; Aswad and Deight, 1983b) are also excellent MAPs for mb-PCMT (Table 6).

Treating MAP-containing brain membranes with Lubrol- $P_{x}$ and CHAPS (Fig. 2) revealed kinetically different time courses of MAP "inactivation" and a $30 \%$ loss in the ability of the CHAPS-treated MAPs to be recognized by the mb-PCMT. The results depicted in Fig. 3 suggest a more complex scenario, however, inasmuch as they demonstrate that bufferpretreated mb-MAPs added to either Lubrol- $\mathbf{P}_{\mathrm{x}}$ or 
CHAPS-pretreated mb-MAPs provided for higher levels of mb-PCMT activity than did the homologous additions of $P_{L}$ to $P_{L}$ and $P_{C}$ to $P_{C}$ (see legend, Fig. 3). These findings suggest that the action of the 2 detergents damaged the mb-MAPs as mb-PCMT substrates whereas their prolonged exposure to buffer at $\mathrm{pH} 6.5$ had no such negative effect.

As recently suggested by Clarke and associates (Clarke, 1985; Murray and Clarke, 1986), Aswad and associates (Aswad, 1984; Johnson and Aswad, 1985a, b; Johnson et al., 1985) and jointly by both groups (O'Connor et al., 1984), the carboxylmethylation of proteins (peptides) by the cytosolic PCMT of brain and other tissues (O'Connor et al., 1984) may occur at the $\alpha$-carboxyl group of atypical $\beta$-linked aspartyl (L-isoaspartyl) residues. These atypical L-isoaspartyl residues may be readily generated in vitro in proteins (peptides) containing asparagine-glycine bonds through a mild base-catalyzed deamidation, the ensuing formation of a cyclic succinimide intermediate and its spontaneous ring opening to yield the normal (aspartyl) and the atypical (isoaspartyl) peptides in variable ratios (Murray and Clarke, 1986). Since Johnson et al. (1985) have shown that exposure of pure bovine brain calmodulin to $0.1 \mathrm{M} \mathrm{MH}_{4} \mathrm{OH}$ dramatically increased its carboxylmethylation by cytosolic PCMT, we subjected a Lubrol- $\mathrm{P}_{\mathrm{x}}$ extract of the membrane proteins contained in pellet No. 6 (Table 3, A1) to $0.05 \mathrm{M} \mathrm{NH}_{4} \mathrm{OH}$ and noted a 4-fold increase in the carboxyl- $\left[{ }^{3} \mathrm{H}\right]$-methylation of its MAPs by the co-present, solubilized PCMT, which appeared to survive the $\mathrm{NH}_{4} \mathrm{OH}$ treatment largely unscathed (Kim, 1984). Furthermore, we also noted that pretreatment of the Lubrol- $\mathrm{P}_{\mathrm{x}}$ and Nonidet P-40 extracts of the membrane proteins of pellet No. 6 with BTI greatly diminished the subsequent effectiveness of $0.05 \mathrm{M} \mathrm{NH}_{4} \mathrm{OH}$ to generate novel carboxyl$\left[{ }^{3} \mathrm{H}\right]$-methylatable residues in the solubilized brain MAPs. This finding is taken as strong evidence in support of the notion that the increase in MAP carboxyl- $\left[{ }^{3} \mathrm{H}\right]$-methylation noted after $\mathrm{NH}_{4} \mathrm{OH}$ (Table 7) reflects the generation in the affected MAPs of atypical L-isoaspartate residues which are known to be the preferred target of PCMT action. Conclusive evidence in favor of this notion is being gathered presently.

Acknowledgements - The research was supported in part by a pilot grant from the National Institute on Aging (NIH), AG-05022.

\section{REFERENCES}

Aswad D. W. (1984) Stoichiometric methylation of porcine adrenocorticotropin by protein carboxyl methyltransfer- ase requires deamidation of asparagine $25 . \mathrm{J}$. biol. Chem. 259, 10714-10721.

Aswad D. W. and Deight E. A. (1983a) Endogenous substrates for protein carboxyl methyltransferase in cytosolic fractions of bovine brain. J. Neurochem. 41, 1702-1709.

Aswad D. W. and Deight E. A. (1983b) Purification and characterization of two distinct isozymes of protein carboxymethylase from bovine brain. $J$. Neurochem. $\mathbf{4 0}$, 1718-1726.

Berti-Mattera L. N., Larocca J. N., Pellegrino de Iraldi A., Pasquini J. M. and Soto E. F. (1984) Isolation of oligodendroglial cells from young and adult whole rat brains using an in situ generated Percoll density gradient. Neurochem. Int. 6, 41-50.

Billingsley M. L. and Balaban C. D. (1985) Protein-Ocarboxylmethyltransferase in the rat brain: High regional levels in the substantia nigra, locus coeruleus and paraventricular nucleus. Brain Res. 358, 96-103.

Billingsley M. L., Kim S. and Kuhn D. M. (1985a) Immunohistochemical localization of protein carboxyl-Omethyltransferase in rat brain neurons. Neuroscience $\mathbf{1 5}$, 159-171.

Billingsley M. L., Kincaid R. L. and Lovenberg W. (1985b) Stoichiometric methylation of calcineurin by protein carboxyl-O-methyltransferase and its effects on calmodulin-stimulated phosphate activity. Proc. natn. Acad Sci. U.S.A. 82, 5612-5616.

Billingsley M. L. and Lovenberg W. (1985) Protein carboxylmethylation and nervous system function. Neurochem. Int. 4, 575-587.

Billingsley M. L., Velletri P. A., Lovenberg W., Kuhn D., Goldenring J. R. and DeLorenzo R. J. (1985c) Is $\mathrm{Ca}^{2+}$ calmodulin-dependent protein phosphorylation in rat brain modulated by carboxylmethylation? $J$. Neurochem. 44, 1442-1450.

Brown F. C. (1984) Protein carboxymethylase isozymes in rat brain subcellular organelle. Biochem. Pharmac. 33, 2921-2923.

Clark R. L., Venkatasubramanian K. and Zimmerman E. F. (1982) Prenatal and postnatal development of protein carboxylmethylation activity in the mouse. Devl Neurosci. 5, $467-473$.

Clarke S. (1985) Protein carboxylmethyltransferases: Two distinct classes of enzymes. A. Rev. Biochem. 54, 479-506.

Diliberto E. J. Jr and Axelrod J. (1974) Characterization and substrate specificity of a protein carboxymethylase in the pituitary gland. Proc. natn. Acad. Sci U.S.A. 71, 1701-1704.

Diliberto E. J. Jr and Axelrod J. (1976) Regional and subcellular distribution of protein carboxymethylase in brain and other tissues. J. Neurochem. 26, 1159-1165.

Farooq M. and Norton W. T. (1978) A modified procedure for isolation of astrocyte- and neuron-enriched fractions from rat brain. $J$. Neurochem. 31, 887-894.

Fischer-Bovenkerk C., Kramer C. M. and Sellinger O. Z. (1986) Protein carboxylmethylation in the aging brain. Trans. Am. Soc. Neurochem. 17, 289.

Gagnon C., Kelly S., Manganiello V., Vaughan M., Odya C., Strittmatter W., Hoffman A. and Hirata F. (1981) Modulation of calmodulin function by enzymatic carboxyl methylation. Nature, Lond. 291, 515-516.

Gupta R. C., Khandelwal R. L. and Sulakhe P.V. (1985) Isolation and characterization of calcineurin from bovine brain. Can. J. Physiol. Pharmac. 63, 1000-1006. 
Hersh L. N. (1985) Characterization of membrane-bound aminopeptidases from rat brain: Identification of the enkephalin-degrading aminopeptidase. $J$. Neurochem. 44, 1427-1435.

Hjelmeland L. M. and Chrambach A. (1984) Solubilization of functional membrane receptors. In: Receptor Biochemistry and Methodology, (Venter J. C. and Harrison L. C., eds), Vol. 1, pp. 35-46. Liss, New York.

Iqbal M. and Steenson T. (1976) Purification of protein carboxymethylase from ox brain. $J$. Neurochem. 27, 605-608.

Jeffery D. R. and Roth J. A. (1984) Characterization of membrane-bound and soluble catechol-O-methyltransferase from human frontal cortex. $J$. Neurochem. 42, 826832

Johnson, B. A. and Aswad, D. W. (1985a) Identification and topography of substrates for protein carboxylmethyl transferase in synaptic membrane and myelin-enriched fraction of bovine and rat brain. $J$. Neurochem. 45, 1119-1127.

Johnson B. A. and Aswad D. W. (1985b) Enzymatic protein carboxylmethylation at physiological $\mathrm{pH}$ : Cyclic imide formation explains rapid methyl turnover. Biochemistry 24, 2581-2586.

Johnson B. A., Freytag N. E. and Aswad D. W. (1985) Protein carboxylmethyl-transferase selectively modifies an atypical form of calmodulin. Evidence for methylation at deamidated asparagine residues. J. biol. Chem. 260, $10913-10916$.

Kim, S. (1984) S-adenosylmethionine: Protein-carboxyl-Omethyltransferase (Protein Methylase II). In: Methods in Enzymology, Vol. 106, pp. 259-309. Academic Press, New York.

Murray E. D. and Clarke S. (1986) Metabolism of a synthetic L-isoaspartyl-containing hexapeptide in erythrocyte extracts. Enzymatic methyl esterification is followed by nonenzymatic succinimide formation. J. biol. Chem. 261, 306-312.

Nagy N. and Delgado-Escueta A. V. (1984) Rapid preparation of synaptosomes from mammalian brain using nontoxic isoosmotic gradient material (Percoll). J. Neurochem. 43, 1114-1123.

O'Connor C. M., Aswad D. W. and Clarke S. (1984) Mammalian brain and erythrocyte carboxylmethyltransferases are similar enzymes that recognize both D-aspartyl- and L-isoaspartyl residues in structurally altered proteins. Proc. natn. Acad. Sci. U.S.A. 82, 7757-7761.

Percy A. K., Moore J. F. and Waechter C. J. (1982) Properties of particulate and detergent-solubilized phospholipid $\mathrm{N}$-methyltransferase activity from calf brain. J. Neurochem. 38, 1404-1412.

Peterson G. L. (1977) A simplification of the protein assay method of Lowry et al., which is more generally applicable. Anal. Biochem. 83, 346-356.

Sellinger O. Z. and Santiago J. C. (1972) Unequal development of two mitochondrial enzymes in neuronal cell bodies and glial cells of rat cerebral cortex. Neurobiology 2, 133-146.

Sellinger O. Z., Azcurra J. M., Johnson D. E., Ohlsson W. G. and Lodin Z. (197I) Independence of protein synthesis and drug uptake in nerve cell bodies and glial cells isolated by a new technique. Nature, New. Biol. 230, 253-256.

Sellinger O. Z., Kramer C., Bovenkerk C., Adams C. and Cykiert A. (1985) A study of the membrane-bound protein carboxylmethyltransferase of brain. Trans. Am. Soc. Neurochem. 16, 1271

Singh I., Singh R., Bhushan A. and Singh A. K. (1985) Lignoceroyl-CoA-ligase activity in rat brain microsomal fraction: Topographical localization and effect of detergents and $\alpha$-cyclodextrin. Arch. Biochem. Biophys. 236, 418-426.

Soby L. M. and Johnson P. (1981) Determination of asparagine and glutamine in polypeptides using Bis(I,Itrifluoroacetoxy)-iodobenzene. Anal. Biochem. 113, 149-153.

Sweetnam P. M. and Tallman J. F. (1986) Regional difference in brain benzodiazepine receptor carbohydrates. J. Pharmac, exp. Ther. 29, 299-306. 